\title{
PRIORITIZING AIRPORT DEVELOPMENT PLAN TO OPTIMIZE FINANCIAL FEASIBILITY
}

\author{
Mohammed Ali BERAWI ${ }^{1}$, Bambang SUSANTONO ${ }^{2}$, Perdana MIRAJ ${ }^{3, *}$, Fitri NURMADINAH ${ }^{4}$ \\ ${ }^{1}$ Civil Engineering, Faculty of Engineering, Universitas Indonesia, Kampus UI, 16424, Depok, Indonesia \\ ${ }^{2,}{ }^{4}$ Center for Sustainable Infrastructure Development, Faculty of Engineering, Universitas Indonesia, \\ Kampus UI, 16424, Depok, Indonesia \\ ${ }^{3}$ Civil Engineering, Faculty of Engineering, Universitas Pancasila, Srengseng Sawah, \\ 12640, DKI Jakarta, Indonesia
}

Received 03 July 2018; accepted 05 November 2018

\begin{abstract}
Air transportation plays a significant role not only in connecting remote and isolated areas but also in enhancing national economic development. Indonesia, a country consisting of more than 17,000 islands, has 162 airports administered by its government through the Directorate General of Civil Aviation (DGCA) of the Ministry of Transportation. In response to budget constraints to expand these airports for services, the government has initiated collaboration with the private sector to develop airports. This paper aims to assist decision makers in deciding which of the 162 airports should be prioritized for partnership based on project feasibility. The study used qualitative and quantitative approaches, employing an analytical hierarchy process (AHP) method, multi-criteria weighting, and financial feasibility to analyze the findings. As a result, the prioritized airports recommended for partnership with the private sector are expressed in a quadrant priority of scale.
\end{abstract}

Keywords: airport choice, financial feasibility, infrastructure, multi-criteria weighting, privatization.

\section{Introduction}

In the era of globalization, the movement of people and goods involves aspects of speed, comfort, and price. These needs require a means of transportation on land, sea, and air. Roads and railways, as part of ground transportation, offer flexibility and ease of access, but the coverage distance is limited (Berawi et al., 2015; Givoni \& Banister, 2007). Sea transport provides an enormous load capacity but requires a longer travel time and is thus more beneficial for transporting goods than people (Couper, 2015; Paixão \& Marlow, 2002). On the other hand, air transport proposes a higher value for the money considering its shorter travel time and longer coverage area compared to other transport means (Bråthen \& Halpern, 2012; Medvedev, Alomar, \& Augustyn, 2017).

Liberalization has been implemented in many countries to accommodate private sector involvement in airport development (Thompson, 2002). European countries have had recent experience with liberalization, whereas just 20 years ago, competition between airports and airlines was more limited (Thelle \& la Cour Sonne, 2018). Presently, the commercialization and privatization of air- ports combined with a common visa policy through the Schengen Convention have dramatically increased air passenger movement in Europe. Germany has experienced a threefold increase of passengers from 1995 to 2015 (World Bank, 2017). The same trend has also occurred in France, Spain, and other European countries.

Researchers and academics have debated the privatization and liberalization of airports over the past decade. Hooper (2002) reviewed privatization in Asia and found it to be constrained by various factors such as policy and railway market competition. In Italy and China, privatization reduce the financial performance of airports (Fasone, Maggiore, \& Scuderi, 2014; Yang, Tok, \& Su, 2008). Furthermore, Gong, Cullinane, and Firth (2012) argued that the framework for achieving success in the privatization of airports depends on many aspects and might differ among countries. In contrast, privatization in Korea is believed to weaken the control of the government but strengthen services for the users (Park, Kim, Seo, \& Shin, 2011).

Despite the prospective debates and discussions about improving the attractiveness of airport development to private investors, there is little evidence to show which

${ }^{*}$ Corresponding author. E-mail: perdanamiraj@gmail.com 
airports should remain managed by the state. This is despite the fact that a framework of airport choice can significantly contribute to the release schedule of the national budget. This issue is crucial for Indonesia, which is categorized as a developing country and is reliant upon the construction of infrastructure projects, such as airport development, funded by the state.

In the last two years, Indonesia has encouraged private sector interest in air transportation through Ministry Regulation No. 193, 2015, which pertains to concessions and a partnership scheme between the government and business entities in the aviation industry. However, involvement by the private sector in air transportation remains limited. In fact, Public Private Partnership (PPP) Book 2017-a document issued by the national development planning agency (Bappenas), which accommodates potential infrastructure projects for partnership-shows that none of the air transportation projects are ready to be offered to investors.

Consequently, as a regulator, the government should carefully consider which airport projects have the potential for private sector investment. This research aimed to prioritize airports by evaluating their financial feasibility to attract private investment. The results of this study are expected to support the decision-making process by related stakeholders. This study also sought to promote potential airports and increase PPP scheme implementation in air transportation. The concept generated from this research can also be used by other similar projects around the world to improve the competitiveness of aviation.

\section{Airports in Indonesia}

According to Ministry Regulation No. KM 11, 2010 involving the national air transportation order, Indonesia's airports are classified into two types; general and exclusive. These categories differ from other classifications, such as ownership-based, management-based, or hierarchy-based. Ownership-based classification categorizes airports into four models: direct ownership by the government, government ownership through airport authorities, mixed ownership (public and private), and private ownership (Doganis, 2005). Management-based classification also divides airports into four models: municipally operated airports, port authorities, airport authorities, and stateoperated airports (Wells, 1992). Last, hierarchy-based classification separates airports into two types: spoke and hub and point to point (Adler, Fu, Oum, \& Yu, 2014). Currently, the hierarchy-based concept is relatively vague, as there is an increasing number of low-cost carriers (LCCs) across the world. Several LCC operators use the hub and spoke type in their local routes by taking the country of origin as the hub.

General airports in Indonesia are managed by stateowned enterprises (SOEs), namely PT. Angkasa Pura I and PT. Angkasa Pura II. On the other hand, the Directorate General of Civil Aviation (DGCA) manages the rest of the airports. Private airports are owned and operated by private companies (mainly oil, plantation, and manufacturing companies) and are restricted from public use. These airports support activities that require speed and secure handling only by the companies. Their construction must follow strict regulations and receive government permits in the initial planning stage. In total, 20 airports of this type exist across the nation. The airport's management classification is shown in Figure 1.

Partnership on airports managed by SOEs is relatively more straightforward compared to those managed by the DGCA. The airport location managed by the SOE is mostly strategic, their size is expandable, and their market is mature. Thus, the return on investment on this type of airport is profitable. In contrast, commercial airports managed by the DGCA are relatively small in terms of size and market. These airports serve mostly remote and isolated parts of Sumatra in the western region of Papua Island in the east of Indonesia. Despite its disadvantages, this type of airport is significant for accessibility, particularly for the eastern part of Indonesia, which is less developed and under-utilized.

Most of the airports managed by the DGCA use the state budget. However, supporting 162 airports still involves an enormous cost to improve its airside and landside infrastructure. The government, as owner of the infrastructure, has attempted to transfer the management of potential airports by the DGCA to business entities, such as SOEs, local government, or private investors, both domestic and international.

One solution is through a public-private partnership (PPP) scheme. This scheme is an alternative approach that has been successfully applied in many sectors to encourage private involvement in public projects and thereby mitigate the limited budget of the government (Ismail, 2013; Osei-Kyei \& Chan, 2015). The PPP scheme in air transportation faces obstacles that could potentially reduce implementation, such as a lack of supported law, limited institutional capacity, and a small return on investment (Carnis \& Yuliawati, 2013). This research was expected to solve PPP problems in air transportation by promoting airports that are highly promising for investment.

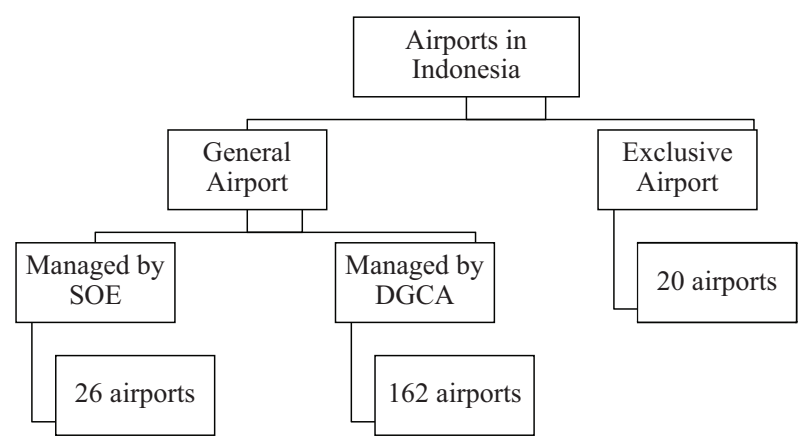

Figure 1. Airport classification in Indonesia 


\section{Methodology}

This research followed three stages to achieve the research objectives. The first stage used the analytical hierarchy process (AHP) method to rank criteria for airport evaluation. AHP has been widely used by researchers and academicians due to its flexible installation, e.g., with fuzzy logic and linear programming, among others (Vaidya \& Kumar, 2006). It also offers simplicity, consistency logic, priority measurement, and process repetition (Saaty, 1980). The second stage uses different types of analysis depending on the type of each criterion, making it difficult to generalize. Thus, each type of analysis was investigated specifically. Airports in the third stage were evaluated by using a rate of return approach. The private sector may seek higher financial feasibility when examining a potential project for partnership. Therefore, it is crucial that the government offer an attractive project with significant feasibility. The proposed research stages can be seen in Figure 2.

In the first stage, research criteria were identified based on a literature review, national regulation, and expert judgment. The criteria were categorized into five criteria and 16 sub-criteria. The first criterion is regional economy and consists of three sub-criteria: gross regional domestic product (GRDP), GRDP to GDP ratio, and featured sector. GRDP is an indicator for understanding the economic condition in a particular area of a country for certain periods by considering the basis of current prices or the basis of constant prices. These criteria are derived from the Decree of Directorate General of Aviation, the Republic of Indonesia, in 2002 about implementation guidance for airport master plans. The report argued that economic development in a region should be considered as one of the primary components for airport development. The current research strengthens this argument by using data from Statistics Indonesia and from many studies that have suggested that regional economies might be generated from GRDP and their economic sector landscape, such as tourism, construction, and industry (Abdul-Rahman \& Berawi, 2002; Berawi, Zagloel, Miraj, \& Mulyanto, 2017; Karim, Rahman, Berawi, \& Jaapar, 2007; Statistics Indonesia, 2018; Woodhead \& Berawi, 2008).

The second criterion is market demand, which plays a significant role in project feasibility, since higher demand will ensure that the operator/airport management will generate the expected revenue. Experts from practitioners and government institutions have suggested that increasing the number of passengers and amount of cargo should be considered when evaluating the best airports for partnership with the private sector, which is concerned with project feasibility and may demand an acceptable rate of return for infrastructure projects proposed by the government. Otherwise, the government must manage the operation and maintenance of airports that serve the economic activity of an area/region but produce low financial feasibility.

Risk is the third criterion for airport evaluation. The literature proposes different risks related to airport development involving the environment, safety, security and health, finances, legal issues, human resources, schedules, costs, communication, and technology (Hong Kong Airport Annual Report, 2011; Nielsen \& Elum, 2007; Price, 2014; Western Sydney Airport, 2014). This study evaluated these risks by consulting with Indonesian experts in aviation and selecting the four greatest risks that must be considered for airport development. These risks involve demand, politics, land acquisition, and tariffs.

Furthermore, as the fourth criterion, government programs should be considered for airport partnerships with the private sector. The assessment was conducted by accounting for two aspects: the Strategic Plan of Transpor-



Figure 2. Proposed phases to generate potential airports managed by the DGCA for partnership 
tation and the National Plan. Four types of airport development were generated from the Strategic Plan of Transportation: airports located in disaster-prone areas, airports located near the border area, airports located along the border and in disaster-prone areas, and airports proposed with the PPP scheme. The last type of airport aims to attract business, and therefore the government must determine a level of feasibility that matches private interest. Thus, airports proposed with the PPP scheme generate a higher score due to stronger support from the government in terms of policy, financing, and other types of support.

Lastly, accessibility aims to provide seamless mobility in transporting passengers and goods from one area to another. Accessibility is related to three criteria: travel time, distance, and the transportation network. Travel time and distance were calculated based on the proximity of the airport to the city center. Airports managed by the DGCA have different infrastructure and supporting conditions than others. Therefore, airports with similar distances may produce different travel time. Both criteria were obtained from the Ministry of Transportation website, Google Maps, and expert judgment. On the other hand, the transportation network is related to the total means of transport to the airport, which may be by bus, private vehicles, railways, and local transport, such as Klotok, Jukung, or Ojek. The details of the criteria and subcriteria are shown in Figure 3.

In this stage, the research criteria were delivered to seven respondents representing regulators, practitioners, investors, and donor institutions. These respondents were chosen through purposive sampling, which targets individuals with the most knowledge and experience (Miles \& Huberman, 1994), particularly in aviation and infrastructure. Two key persons were from the Ministry of Transportation in the airport directorate and public-private partnership directorate. Both respondents were involved in formulating suitable airports for partnership with investors. Another key person was an infrastructure expert

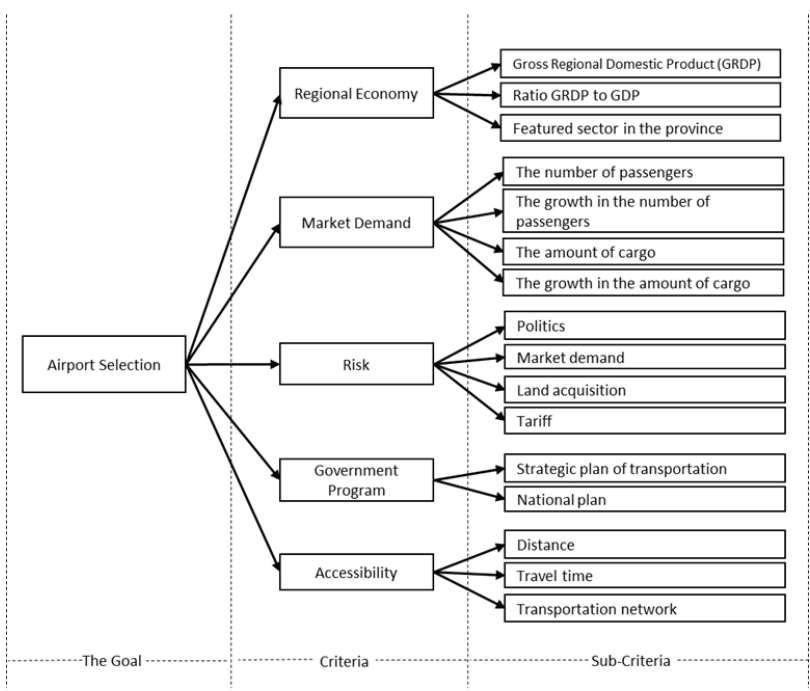

Figure 3. Criteria and sub-criteria to determine airport priorities who had been involved in evaluating airports in Indonesia in terms of economic feasibility. Two practitioners were consultants for airport development in the southern part of Java and had years of experience in assisting the airport directorate in the Ministry of Transportation. Experts from investor and donor institutions have been involved in the decision-making process together with the Ministry of Transportation in the airport sector during the past five years. The minimum requirement for the respondents was that they held a post-graduate degree and had more than 10 years of experience in the aviation sector. It is argued that this study's results are both valid and credible given the respondents' backgrounds.

The AHP method was then used to analyze the research findings in this stage. AHP is a method for evaluating complex problems through an organized and structured technique combining mathematics and psychology (Saaty, 1980, 2008). This method uses qualitative and quantitative approaches to arrive at a final decision. The qualitative approach visualizes problems through a multilevel hierarchy structure (Crowe, Noble, \& Machimada, 1998; Wong \& Li, 2008). Meanwhile, the quantitative approach selects essential factors to less critical factors using a scaling system (Cheung, Lam, Leung, \& Wan, 2001; Ucler, 2017). Researchers and academics have suggested phases in the AHP process (Yoo \& Choi, 2006; Zietsman \& Vanderschuren, 2014). First, problems and expected objectives were identified; then, the objectives were structured down to the alternative selections with a hierarchy system. A pairwise comparison was proposed to evaluate each element at each objective level using an intensity scale of importance, as shown in Table 1.

Eigenvalue and consistency tests were conducted, respectively, to evaluate the final priorities of the alternatives and to rank potential airports for partnership based on the five identified criteria. A consistency ratio (CR) in the consistency test was used to measure inconsistency in the judgment. Generally, a CR of less than $10 \%$ was considered acceptable.

Table 1 . Intensity scale of importance

\begin{tabular}{|l|l|l|}
\hline $\begin{array}{l}\text { Scale } \\
\text { Value }\end{array}$ & Definition & Explanation \\
\hline 1 & Equal & Two elements equally important \\
\hline 3 & Moderate & $\begin{array}{l}\text { An element is slightly important } \\
\text { over another }\end{array}$ \\
\hline 5 & Strong & $\begin{array}{l}\text { An element is definitely important } \\
\text { over another }\end{array}$ \\
\hline 7 & Very Strong & $\begin{array}{l}\text { An element is very strongly } \\
\text { important over another }\end{array}$ \\
\hline 9 & Extreme & $\begin{array}{l}\text { An element is absolutely } \\
\text { important over another }\end{array}$ \\
\hline $2,4,6,8$ & $\begin{array}{l}\text { Intermediate } \\
\text { between Values }\end{array}$ & $\begin{array}{l}\text { A numerically interpolated } \\
\text { compromise judgment }\end{array}$ \\
\hline
\end{tabular}

Note: $2,4,6,8$ can be used to express intermediate values - 1.1, 1.2, etc. for elements that are very close in importance. 
In the second stage, 162 airports managed by the DGCA were evaluated based on criteria and sub-criteria and scaled using linear interpolation. Each criterion has different tools of evaluation but mostly use a band of 10. Unlike other evaluations, the featured sector in the regional economy criteria used an LQ analysis and Klassen typology analysis. LQ is an indirect measurement method that evaluates the concentration or dominance of clusters, groups, industries, or any particular sector in the region (district/city/province) compared to a larger comparison area, such as province or nation (Berawi et al., 2017). LQ exposes unique local/regional features rather than the provincial/national average. This method has been used by various sectors, such as the marine (Morrissey, 2014), industrial (Billings \& Johnson, 2012), and foods (Leslie, Frankenfeld, \& Makara, 2012) sectors. In general, the LQ is a ratio between two proportions of values of the investigated aspect. LQ can be expressed using the following formula:

$$
L Q_{i}=\frac{e_{i} / e}{E_{i} / E},
$$

where: $L Q_{i}=L Q$ value for $i$ sector in a district; $e_{i}=$ GRDP for $i$ sector in a district; $e=$ GRDP for whole sector in a district; $E_{i}=$ GRDP for sector $i$ in a province of a district; $E=$ GRDP for whole sector in a province of a district.

LQ will produce coefficients from 0 to an infinite value. LQ $<1$ means the sector generates lower degree of specialization or concentration compared with the larger comparison area. On the other hand, $L Q=1$ indicates that the region has similar degrees of specialization or concentration. LQ $>1$ shows that the investigated sector has a higher level of specialization or concentration within the area. Using this formula, we can determine the potential sector for development in an area by choosing the sector that shows an LQ value higher than 1. Conversely, a Klassen typology was used to categorize regional economic sectors into four characteristics, namely developed sector, stagnant sector, developing sector, and underdeveloped sector. The classification expressed by quadrant is shown in Figure 4.

\begin{tabular}{c|c} 
Quadrant I & Quadrant II \\
Developed Sector & Stagnant Sector \\
$\mathrm{s}_{\mathrm{i}}>\mathrm{s}$ and $\mathrm{s}_{\mathrm{i}}>\mathrm{sk}$ & $\mathrm{s}_{\mathrm{i}}<\mathrm{s}$ and $\mathrm{sk}_{\mathrm{i}}>\mathrm{sk}$ \\
\hline Quadrant III & Quadrant IV \\
Developing Sector & $\begin{array}{c}\text { Under }- \text { developed } \\
\text { Sector }\end{array}$ \\
$\mathrm{s}_{\mathrm{i}}>\mathrm{s}$ and $\mathrm{sk}_{\mathrm{i}}<\mathrm{sk}$ & $\mathrm{s}_{\mathrm{i}}<\mathrm{s}^{\text {and }} \mathrm{sk} \mathrm{k}_{\mathrm{i}}<\mathrm{sk}$
\end{tabular}

Figure 4. GRDP classification based on Klassen typology

where: $s i=$ growth rate of analyzed regional sector; $s \quad=$ growth rate of referenced regional sector; ski = contribution of analyzed regional sector; $\mathrm{sk}=$ contribution of referenced regional sector.
Furthermore, in the third stage, the financial feasibility of selected airports was evaluated by using a life-cycle cost approach, which considers several indicators, such as net present value (NPV), internal rate return (IRR), and payback period $(\mathrm{PbP})$, as well as minimum attractiveness rate of return (MARR). NPV represents future cash flows that are discounted at the present time, while IRR is a discount rate for generating an NPV equal to zero. IRR aims to estimate profits gained by the investor against their investment. $\mathrm{PbP}$ is the length of time needed to recover the investment cost of a project. MARR in infrastructure projects depends on many factors; however, in this case, the minimum was about $12 \%$, which is considered acceptable for investment. The results demonstrate the priority airports for partnership and the most innovative way to undertake the project (Berawi, 2006; Berawi, Miraj, Berawi, Silvia, \& Darmawan, 2016).

The research estimated total investment cost and operational cost as well as revenues from each airport. In conducting the financial analysis, several assumptions were made: a construction period of three years, a project life cycle of about 25 years, and an interest rate of $12 \%$. The interest rate value followed the common rate in Indonesia for infrastructure and transportation project development. The tax was set at about 15\% of total income. Depreciation consists of two types: construction and equipment. The first depreciates $40 \%$ during the construction stage, while the second depreciates at $10 \%$ annually. Operational and maintenance costs consist of maintenance, insurance, staff, materials, depreciation, debt, and interest. Furthermore, revenue follows Ministry of Transportation Regulation No. 36, 2014 about guidelines for airport tariffs and charges. The revenue should comprise two types: aeronautic and non-aeronautic. Aeronautic revenue considers seven items, includes landing, parking, storing, passenger service, cargo, check-in counter, and aviobridge. On the other hand, non-aeronautic may consist of but is not limited to concession activities, vehicle parking, advertisement, ground handling, warehousing, and cargo, as well as other facilities that might generate revenues from airport service.

\section{Results and discussion}

\subsection{First stage - criteria and sub-criteria ranking}

Questionnaires completed by the experts were processed using the AHP method to generate ranking and weighting scores from each criterion and sub-criterion. The questionnaire followed a hierarchy system (see Figure 3), and the formatting of which is presented in the Appendix. Respondents filled out the form, which included a 1-9 scale of importance, and the results were processed using multicriteria decision analysis. The results showed that market demand was the highest criterion, with 0.410 . This was followed by the government program (0.210), accessibility (0.144), risk (0.136), and regional economy (0.100).

In terms of the regulator perspective, market demand plays a significant role in attracting investment. Airports 
with a large number of passengers and large amount of cargo will likely be considered for partnership. Two regulators ranked the government program as fourth and fifth rank. They argued that the government-produced program would tend to change frequently in the future and deviate from original planning due mostly to limited funds and resources. Therefore, these criteria play an insignificant role in airport feasibility.

In contrast, practitioners from the operator and donor institutions considered the government program to be the second-highest factor for improving the attractiveness of airport projects. They believed that compatibility between project development and government programs would increase project sustainability in the long term. In the case of donor institutions, loans or grants are require in the government program to improve people's livelihoods and enhance national competitiveness. Furthermore, academic and investor respondents argued that market demand and risk criteria are the two crucial aspects for airport development. Investors will evaluate the feasibility of the project based on its potential risk to the company. The overall weighting and ranking for the criteria can be seen in Table 2 .

Table 2. Weighting and ranking for each criteria

\begin{tabular}{|l|c|c|}
\hline \multicolumn{1}{|c|}{ Criteria } & Weighting & Ranking \\
\hline Regional Economy & 0.100 & 5 \\
\hline Market Demand & 0.410 & 1 \\
\hline Risk & 0.136 & 4 \\
\hline Government Program & 0.210 & 2 \\
\hline Accessibility & 0.144 & 3 \\
\hline
\end{tabular}

The analysis also shows the ranking for each subcriterion. It may consist of a weighting process among sub-criteria in specific criteria (local weighting) and a weighting of all sub-criteria across criteria (global weighting). Global weighting may be generated from the multiplication of sub-criteria by their main criteria. The global weighting score will illustrate the sub-criteria that make significant contributions to airport selection. The weighting and ranking can be seen in Table 3 .

The analysis also shows each respondent's CR. Respondents' $C R$ ranged from 0.000 to 0.116 . The $C R$ value showed that $85.71 \%$ of respondents' replies were consistent, which is an acceptable percentage according to this study. The weighting and ranking of the results were used to evaluate the potential of different airports for partnership with the private sector.

\subsection{Second stage - airport assessment}

\subsubsection{Regional economy criteria}

The regional economy criteria consisted of three sub-criteria: GRDP, the ratio of GRDP, and the featured sector in the province. The GRDP figure was retrieved from Statistics Indonesia for the 2006 to 2010 period. The highest GRDP was about 29,084,100 (million) rupiah, or equal to a band of 10, and the lowest GRDP was 55,360,000 (million) rupiah, or equal to a band of 1 . On the other hand, the ratio of GRDP to GDP will ranked which district/regency that highly contributes to the national economy. If the proportion was $>1$, then the district/regency contributed significantly to national economic development. The results show that the ratio was about 4.70 to 0.01 . Last, the featuhred

Table 3. Weighting and ranking for sub-criteria

\begin{tabular}{|c|c|c|c|c|c|}
\hline Criteria & Sub-Criteria & Local Weighting & $\begin{array}{c}\text { Local } \\
\text { Ranking }\end{array}$ & $\begin{array}{c}\text { Global } \\
\text { Weighting }\end{array}$ & $\begin{array}{c}\text { Global } \\
\text { Ranking }\end{array}$ \\
\hline \multirow[t]{3}{*}{ Regional Economy } & GRDP & 0.506 & 1 & 0.051 & 8 \\
\hline & $\begin{array}{l}\text { Ratio of GRDP to featured sector in } \\
\text { the province }\end{array}$ & 0.170 & 3 & 0.017 & 14 \\
\hline & The featured sector in the province & 0.325 & 2 & 0.032 & 12 \\
\hline \multirow[t]{4}{*}{ Market Demand } & The growth in number of passengers & 0.273 & 2 & 0.112 & 3 \\
\hline & The number of passengers & 0.403 & 1 & 0.165 & 1 \\
\hline & The amount of cargo & 0.126 & 4 & 0.052 & 7 \\
\hline & The growth in the amount of cargo & 0.198 & 3 & 0.081 & 5 \\
\hline \multirow[t]{4}{*}{ Risk } & Political & 0.177 & 3 & 0.024 & 13 \\
\hline & Demand & 0.349 & 2 & 0.048 & 9 \\
\hline & Land acquisition & 0.353 & 1 & 0.048 & 9 \\
\hline & Tariff & 0.121 & 4 & 0.016 & 15 \\
\hline \multirow{2}{*}{$\begin{array}{l}\text { Government } \\
\text { Program }\end{array}$} & Strategic Plan of Transportation & 0.541 & 1 & 0.114 & 2 \\
\hline & National Plan & 0.460 & 2 & 0.096 & 4 \\
\hline \multirow[t]{3}{*}{ Accessibility } & Distance & 0.109 & 3 & 0.016 & 15 \\
\hline & Travel time & 0.337 & 2 & 0.048 & 9 \\
\hline & Transportation network & 0.555 & 1 & 0.080 & 6 \\
\hline
\end{tabular}


sector in this research used the LQ approach and Klassen typology analysis to determine the ranking. The featured sector considered four aspects: the value of tourism and trading $\left(\mathrm{GRDP}_{\mathrm{p}}\right)$, the average GRDP of the national tourism and trading sector $\left(G \mathrm{GPP}_{\mathrm{i}}\right)$, the growth of GRDP in the tourism and trading sector $\left(\mathrm{G}_{\mathrm{p}}\right)$, and the average growth of GRDP in the tourism and trading sector $\left(\mathrm{G}_{\mathrm{i}}\right)$.

Klassen analysis regulated the quadrants into following a band of the score: Quadrant I (8-10), Quadrant II (57.9), Quadrant III (3-4.9), and Quadrant IV (1-2.9). The average growth of the sector $\left(\mathrm{G}_{\mathrm{i}}\right)$ is about $8.69 \%$. Unlike Klassen analysis, LQ only uses the value of tourism and trading $\left(\mathrm{GRDP}_{\mathrm{p}}\right)$ and the average GRDP of the national tourism and trading sector $\left(\mathrm{GRDP}_{\mathrm{i}}\right)$. It was expressed by a ratio of about 2.37 to 0.02 . Both Klassen analysis and LQ analysis were then combined to generate the best alternatives for the featured sector.

Three sub-criteria were then evaluated to produce the overall assessment of airports. The highest score was for Cut Nyak Dien Airport in Kutai Kartanegara, with 6.06, which was followed by three airports, each of which scored above 5.0: Lasikin Airport in Mimika city, Teuku Cut Ali in the Mimika regency, and Maimum Saleh Airport in Cilacap. Six airports managed to score from 4.0 to 5.0 , while others only scored from 0.65 to 3.61 . The results of the regional economy assessment are shown in Figure 5.

\subsubsection{Market demand criteria}

These criteria consist of four sub-criteria: the number of passengers $(\mathrm{P})$, the growth in the number of passengers $\left(\mathrm{P}_{\mathrm{i}}\right)$, the amount of cargo $(\mathrm{C})$, and the growth in the amount of cargo $\left(\mathrm{C}_{\mathrm{i}}\right)$. In this research, the data for passengers and cargo were from the 2006-2010 period. Previous studies have shown that the range of the passengers is about 767,858 to 274 . The average number of passengers $\left(\mathrm{P}_{\mathrm{j}}\right)$ was about 88,043 , while the average growth in the number of passengers $\left(\mathrm{P}_{\mathrm{k}}\right)$ was about $13.48 \%$.

In terms of passengers, the research categorized each airport into groups. Group I included airports where (P) was higher than $\left(\mathrm{P}_{\mathrm{j}}\right)$ and $\left(\mathrm{P}_{\mathrm{i}}\right)$ was higher than $\left(\mathrm{P}_{\mathrm{k}}\right)$. Group

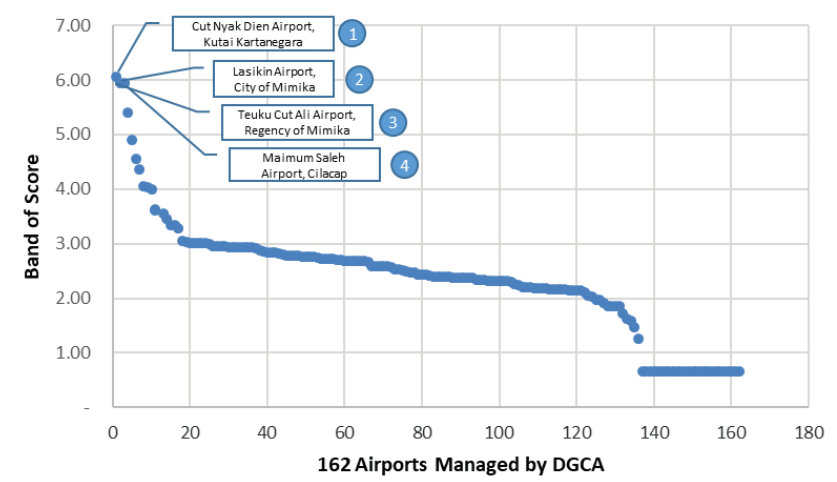

Figure 5. The overall scoring of regional economy criteria in 162 airports
II included airports where $(\mathrm{P})$ was higher than $\left(\mathrm{P}_{\mathrm{j}}\right)$ and $\left(\mathrm{P}_{\mathrm{i}}\right)$ was lower than $\left(\mathrm{P}_{\mathrm{k}}\right)$. Group III included airports where $(\mathrm{P})$ was lower than $\left(\mathrm{P}_{\mathrm{j}}\right)$ and $\left(\mathrm{P}_{\mathrm{i}}\right)$ was higher than $\left(\mathrm{P}_{\mathrm{k}}\right)$. Group IV included airports where $(\mathrm{P})$ was lower than $\left(\mathrm{P}_{\mathrm{j}}\right)$ and $\left(\mathrm{P}_{\mathrm{i}}\right)$ was lower than $\left(\mathrm{P}_{\mathrm{k}}\right)$. The band ranged from 8 to 10,6 to $7.9,4$ to 5.9 , and 1 to 3.9 , respectively. The assessment using the number and growth in the number of passengers showed that Sentani Airport in Jayapura, Papua had an average score of 9.75, followed by Fatmawati Soekarno Airport in Bengkulu, Juwata Airport in Tarakan, and Sultan Babullah Airport in Ternate, all of which scored above 9.0.

In terms of cargo, an additional assessment was conducted, because the amount of cargo among airports varies significantly. The amount of cargo was below 15,000 tons at many airports, while for a few others it was more than 15,000 tons. Airports with a higher amount of cargo were evaluated using a band range from 8 to 10 . The maximum amount of cargo was 35,918 tons, while the minimum was about 15,757 tons. The growth of airports in this category ranged from $25.72 \%$ to $8.27 \%$.

Furthermore, cargo with a capacity lower than 10,000 tons were categorized using a similar approach as that used for passengers but with a different band. The categories ranged from 6 to $7.9,4$ to $5.9,2$ to 3.9 , and 0.1 to 1.9. The cargo ranged from 2,209 tons to 3 tons, and the average growth was from $36.50 \%$ to $7.62 \%$. The assessment showed that the average growth in the amount of cargo $\left(C_{k}\right)$ was $17.80 \%$, and the average load $\left(C_{j}\right)$ was 0.52 tons. The results show that Wamena Airport and Nabire Airport have the highest score, at about 9.79 and 9.0, respectively. The total amount of cargo in airports managed by the DGCA is shown in Figure 6.

The overall rating of the market demand criteria shows that Sentani Airport in Jayapura has the highest airport score, with 9.15, followed by Fatmawati Soekarno Airport in Bengkulu and Wamena Airport in Wamena, with scores in the range of 8.0 to 9.0. Two airports managed to score from 7.0 to 8.0, and four airports scored from 6.0 to 7.0. Others had insignificant scores below 6.0. Details of the assessment are shown in Figure 7.

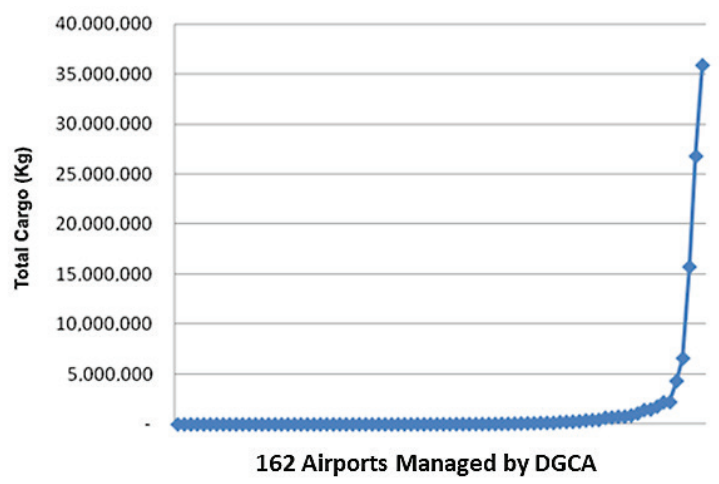

Figure 6. Total cargo in airports managed by the DGCA 


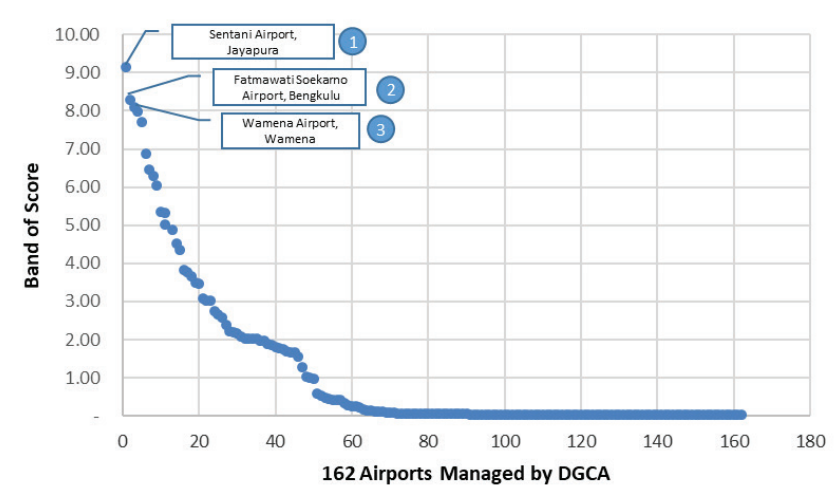

Figure 7. The overall scoring of market demand criteria in 162 airports

\subsubsection{Risk criteria}

The risk criteria considered four sub-criteria: demand, tariffs, politics, and land acquisition. Those criterion are obtained from literature and initial interview from related stakeholder in Indonesia aviation sector. Moreover, this study investigated the fluctuation of additional passengers from 2006 to 2010. It assumed that airports with erratic demand would show a higher risk of market demand compared to airports with a stable number of passengers. The variation in passenger movement was explored using linear regression and was expressed by $\mathrm{R}^{2}$. In contrast with other calculations, in these sub-criteria, the assessment of airports was divided into two groups: airports with regular flights, and airports with non-regular/charter flights. This assumption was used to balance the scoring and differentiate the gap in demand between them. In regular flights, the scale ranged from 4 to 10 , while for non-regular/charter flights, the scale ranged from 0.1 to 3 . The results show that the $\mathrm{R}^{2}$ was about 0.951 to 0.001 for regular flights and 0.93 to 0.021 for non-regular/charter flights.

Airport projects involve substantial costs for development. Return on investment is generated from the revenue during the operational stage. Higher initial costs, as well as operational and maintenance costs and other related expenses, will undoubtedly correlate with higher tariffs charged by the operators. However, they should also consider other aspects, such as the availability to pay (ATP) and willingness to pay (WTP) of users and regulatory permits, when adjusting tariffs to the expected level. Thus, the risk of tariffs plays a significant role in project feasibility.

A project is considered feasible when the NPV is greater than zero. The NPV is affected by revenues and is correlated with the tariff adjustment. When the NPV is below or near zero, investors or operators tend to increase tariffs due to the limited revenue the project may generate. Therefore, a higher NPV generated by each airport will lead to a higher score for the assessment. According to the NPVs of the 162 airports managed by the DGCA, the highest NPV was about 206,396,812,123, and the lowest was about $-334,049,346,952$.

Furthermore, the risk of politics refers to any policy or political intervention in a district/regency that affects the project in terms of financial losses. Although politics can hardly be quantified, this study assumed rioting (e.g., among citizens, between citizens and law enforcers, among tribes, among others) as an indicator for determining the score of a district/regency. No disturbance was equal to 10, and the lowest score was about 5.62 for 27 riots. Lastly, land acquisition is mostly handled by the local or central government. The airports in districts/regencies without land acquisition problems were equal to a band of 10 , while any issues arising from this matter were similar to a band of 0 .

Overall, the assessment shows that eight airports managed to score above 9.0: Silangit Airport in Siborong-borong; Wolter Monginsidi Airport in Haluoleo, Kendari; Fatmawati Soekarno Airport in Bengkulu; Hananjoeddin Airport in Tanjung Pandan; Radin Inten II Airport in Lampung; Mutiara Airport in Palu; Tjilik Riwut Airport in Palangkaraya; and Sultan Babullah Airport in Ternate.

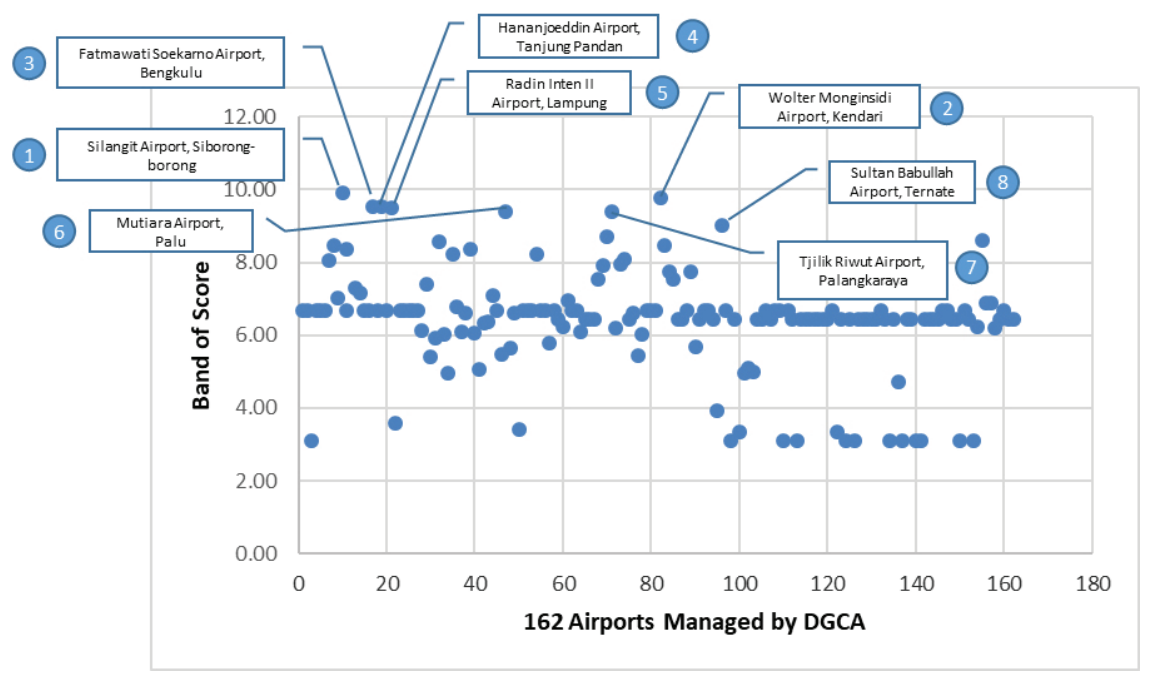

Figure 8 . The overall scoring of risk criteria in 162 airports 
Eleven airports scored between 8.0 to 9.0, while the others scored from 3.10 to 7.94 . The full score of risk criteria is shown in Figure 8.

\subsubsection{Government program criteria}

These criteria consider the Strategic Plan of Transportation (Renstra) and the National Plan. The assessment used three bands: 0,5 , and 10. In term of Renstra, a band of 0 occurred when the project was outside of strategic planning; a band of 5 occurred when the project was included in the program (located at the border, is disaster-prone, attempts to use PPP, or is covered in the PPP book). In terms of the government program, a band of 10 occurred when the project used a PPP scheme and was covered in the National Plan.

A band of 5 occurred when the project used a state budget, and a band of 0 occurred when the project was excluded from the National Plan. The assessment shows that only two airports scored higher than 5.0: Juwata Airport in Tarakan and Sentani Airport in Jayapura. Others scored from 0.0 to 2.70. Details are shown in Figure 9.

\subsubsection{Accessibility criteria}

Accessibility criteria relate to distance, transportation network, and travel time. The sub-criteria of distance were calculated from the airport to the city center of the district/regency. The measurements were generated from various methods, such as the Ministry of Transportation website, Google Maps, and interviews with local respondents. The distance ranged from about $1 \mathrm{~km}$ to $680 \mathrm{~km}$.

The transportation network was measured based on the whole route to the airport. According to the analysis, the highest number of routes was 11, while the lowest was 1 . Lastly, travel time was assumed to be based on a similar speed of about $50 \mathrm{~km} /$ hour for every airport. Thus, the results show that the range from the airport to the city center was about 812 minutes to 1.2 minutes. In total, 82 airports managed to score from 9.0 to 10.0 ; another 13 airports scored from 8.0 to 9.0 . Thirty-two airports scored from 7.0 to 8.0, while the remainder scored from 1.0 to 6.99 . A detailed assessment of the accessibility criteria is shown in Figure 10.

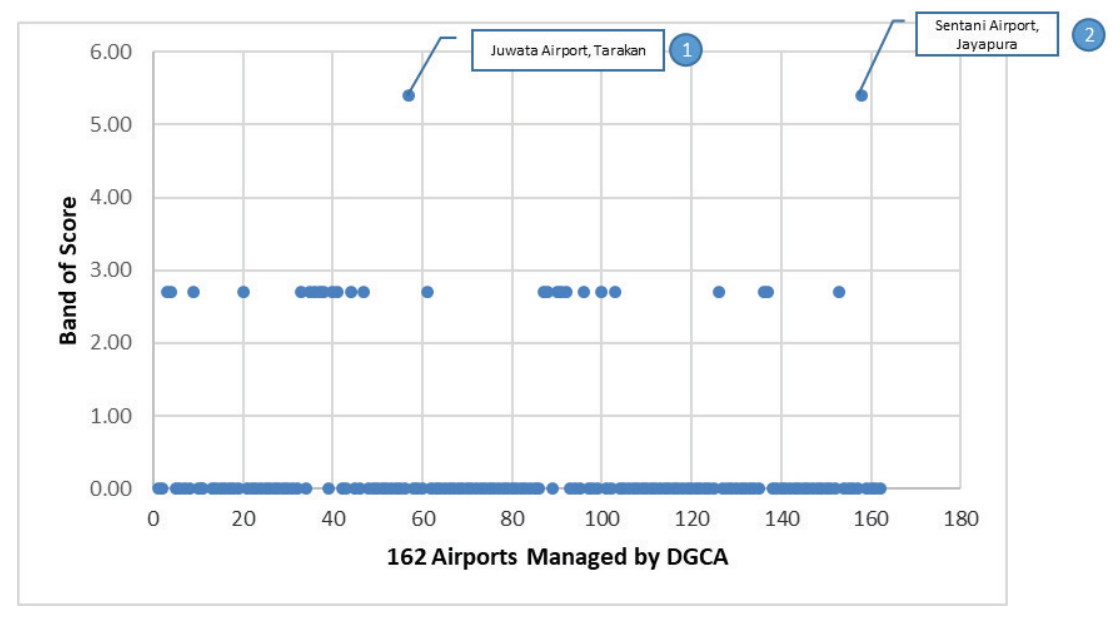

Figure 9. The overall scoring of government program criteria in 162 airports

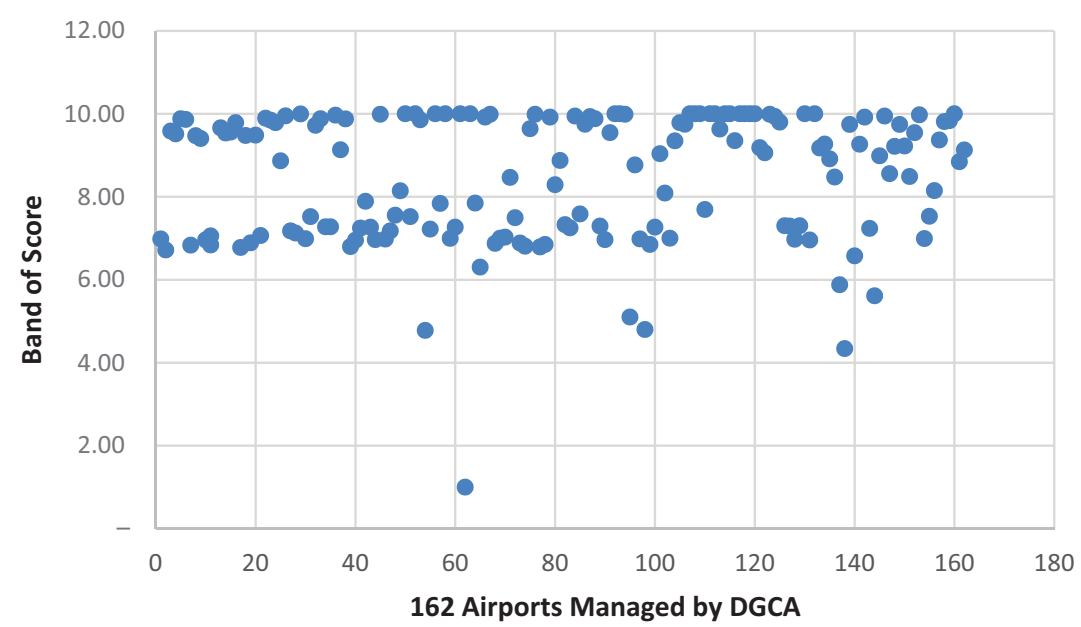

Figure 10. The overall scoring of accessibility criteria in 162 airports 


\subsubsection{Overall assessment of 162 airports}

According to the five criteria and 16 sub-criteria in the above analysis, an overall scoring of airports can be generated. This scoring follows the formula:

$$
y=41.04 x_{1}+20.99 x_{2}+13.57 x_{3}+14.37 x_{4}+13.57 x_{5},
$$

where: $x_{1}=$ Market Demand; $x_{2}=$ Government program; $x_{3}=$ Risk; $x_{4}=$ Accessibility; $x_{5}=$ Regional economy.

The summary of the stage 2 assessment of the 162 airports managed by the DGCA is shown in Figure 11. The circle in red is the highest score, followed by orange, green, and blue.

The assessment shows a total output range from 7.39 to 0.98 . The analysis shows the 10 airports with the highest potential for partnership: Sentani Airport in Jayapura, Juwata Airport in Tarakan, Fatmawati Soekarno Airport in Bengkulu, Sultan Babullah Airport in Ternate, Radin Inten II Airport in Lampung, Tjilik Riwut Airport in Palangkaraya, Wolter Monginsidi Airport in Kendari, Mutiara Airport in Palu, Rendani Airport in Manokwari, and Jalaluddin Airport in Gorontalo.

\subsection{Stage three - financial feasibility analysis}

Financial feasibility analysis is an assessment meant to ensure that a project obtains the highest criteria value and is financially viable. According to Boardman et al. (2010), a project is defined as feasible if NPV $>0$ and IRR $>$ discount rate, and if the payback period value for an airport managed by the DGCA is less than eight years. The analysis included only the 10 airports that showed the greatest potential value for a partnership with a business entity.

First, the initial movement of passengers and cargo was forecasted to 2037. This output determined the revenue for the airport project. The initial cost used a benchmark from a similar project, which was also developed by the DGCA, and was multiplied by the cost construction index. Other parameters used to evaluate the financial analysis can be seen in Table 4 and include but are not limited to depreciation, the interest rate, and the operation and maintenance cost (e.g., staff, materials, capital expenditure).

The analysis produced the most promising potential airports, and a summary of financial assessment is shown in Table 4. The location of each airport can be seen in Figure 12.

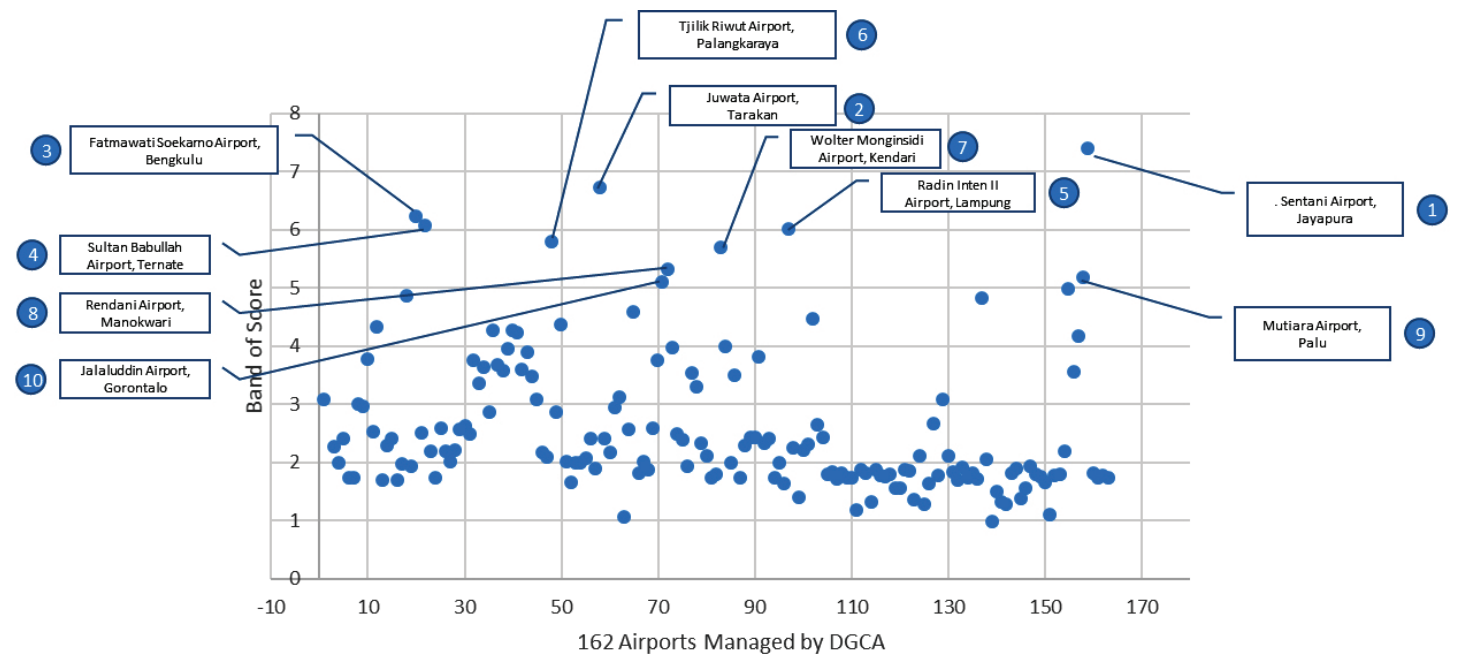

Figure 11. Assessment summary of airports managed by the DGCA

Table 4. Parameters for financial analysis

\begin{tabular}{|l|l|}
\hline \multicolumn{1}{|c|}{ Parameters } & \\
\hline Construction period & 3 years \\
\hline Project life cycle & 25 years \\
\hline Cost construction index & Depends on the location of airports \\
\hline Interest rate & $12 \%$ \\
\hline Transportation sector inflation & $1.63 \%$ \\
\hline Depreciation for construction & $40 \%$ during construction stage \\
\hline Depreciation for equipment & $10 \%$ annually \\
\hline Investment cost & Runway, taxiway, apron, terminal, and car park (Based on DGCA Report) \\
\hline Operation and maintenance cost & Maintenance, insurance, staff, materials, depreciation, debt, and interest \\
\hline Revenues & Aeronautics and non-aeronautics \\
\hline
\end{tabular}




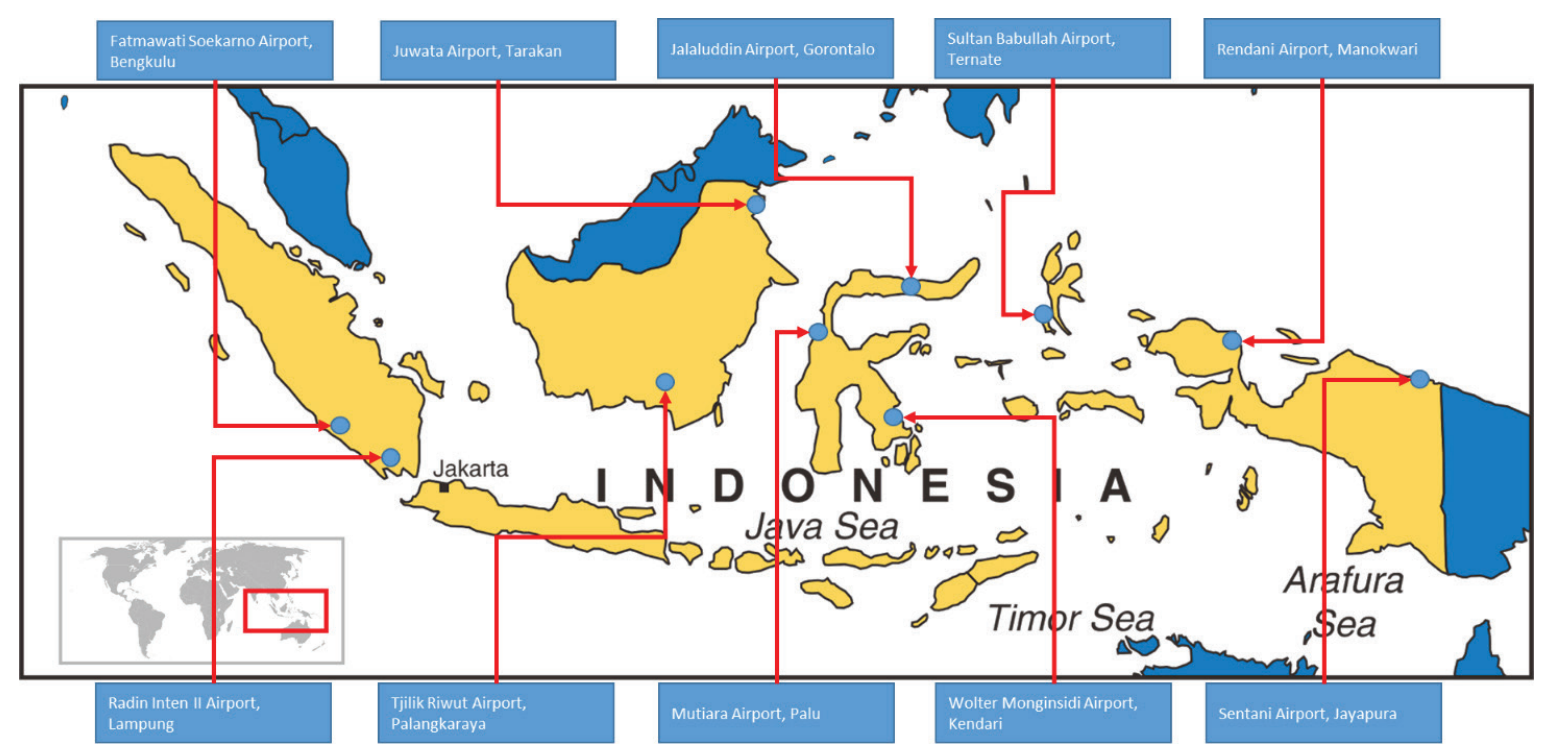

Figure 12. Location of 10 potential airports for partnership

Table 5. Summary of financial analysis

\begin{tabular}{|l|c|c|}
\hline \multicolumn{1}{|c|}{ Airport } & IRR & PBP \\
\hline Radin Inten II/Lampung & $16.12 \%$ & 12.16 \\
\hline Fatmawati Sukarno/Bengkulu & $14.62 \%$ & 12.87 \\
\hline Mutiara/Palu & $13.22 \%$ & 13.82 \\
\hline Haluoleo/Kendari & $12.01 \%$ & 14.59 \\
\hline Juwata/Tarakan & $11.00 \%$ & 15.34 \\
\hline Tjilik Riwut/Palangkaraya & $8.85 \%$ & 16.84 \\
\hline Sentani/Jayapura & $8.33 \%$ & 17.14 \\
\hline Sultan Babullah/Ternate & $7.60 \%$ & 17.87 \\
\hline Rendani/Manokwari & $1.89 \%$ & 23.05 \\
\hline Djalaluddin/Gorontalo & $\mathrm{n} / \mathrm{a}$ & $>25$ \\
\hline
\end{tabular}

Based on the financial feasibility analysis that shown in Table 5 and a MARR above 12\%, the most feasible airports are Radin Inten Airport in Lampung, Fatmawati Sukarno Airport in Bengkulu, Mutiara Airport in Palu, and Haluoleo Airport in Kendari, respectively. The results also outline airport priority for decision makers to determine the best alternatives for development. These results are shown in Figure 13.

\section{Conclusions}

Infrastructure is a means of supporting economic activity and a prerequisite for advancing national competitiveness on a global scale. The quality and availability of infrastructure are crucial not only to increasing the movement of people and the distribution of goods but also to improving quality of life in a country. Air transportation is believed to be the most reliable means of transport in terms of speed and coverage area. Indonesia, with its more than

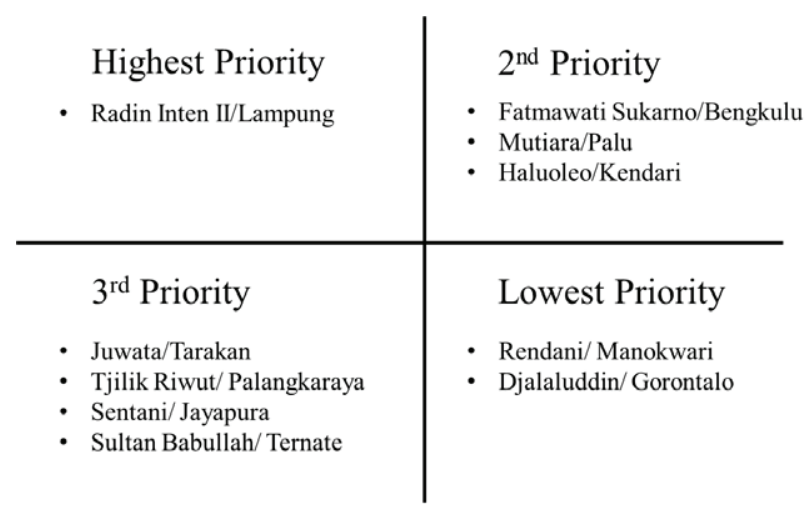

Figure 13. Airport prioritization

17,000 islands, urgently requires airports to be able to connect one area to others equally.

There are 162 commercial airports managed by the DGCA in the Republic of Indonesia that have the potential for partnership with a business entity. The research output offers three staging processes for evaluating the most promising airports: criteria assessment, airport assessment using a scoring system, and financial feasibility estimation. The criteria include five aspects for consideration in developing commercial airports managed by the government: market demand, the government program, risk, accessibility, and regional economy. The airport assessment proposed 10 airports with the potential to attract private investment. The study generated the proposed airports' development in a quadrant priority of scale based on project feasibility. As a result, Radin Inten Airport in Lampung, followed by Fatmawati Sukarno Airport in Bengkulu, Mutiara Airport in Palu, and Haluoleo Airport in Kendari, have the highest priority for partnering with the private sector. 


\section{References}

Abdul-Rahman, H., \& Berawi, M. A. (2002). Managing change in construction contracting. Contract Management, 42, 10-16.

Adler, N., Fu, X., Oum, T. H., \& Yu, C. (2014). Air transport liberalization and airport slot allocation: the case of the Northeast Asian transport market. Transportation Research Part A: Policy and Practice, 62, 3-19. https://doi.org/10.1016/j.tra.2014.02.003

Berawi, M. A. (2006). Distinguishing concept types in function models during the act of innovation (Unpublished doctoral dissertation). Oxford Brookes University.

Berawi, M. A., Berawi, A. R. B., Prajitno, I. S., Nahry, N., Miraj, P., Abdurachman, Y., Tobing, E., \& Ivan, A. (2015). Developing conceptual design of high speed railways using value engineering method: creating optimum project benefits. International Journal of Technology, 6(4), 670-679. https://doi.org/10.14716/ijtech.v6i4.1743

Berawi, M. A., Miraj, P., Berawi, A. R. B., Silvia, \& Darmawan, F. (2016). Towards self-sufficient demand in 2030: analysis of life-cycle cost for Indonesian energy infrastructure. International Journal of Technology, 7(8), 1444-1453.

https://doi.org/10.14716/ijtech.v7i8.6882

Berawi, M. A., Zagloel, T. Y., Miraj, P., \& Mulyanto, H. (2017). Producing alternative concept for the trans-sumatera toll road project development using location quotient method. Procedia Engineering, 171, 265-273.

https://doi.org/10.1016/j.proeng.2017.01.334.

Billings, S. B., \& Johnson, E. B. (2012). The location quotient as an estimator of industrial concentration. Regional Science and Urban Economics, 42(4), 642-647.

https://doi.org/10.1016/j.regsciurbeco.2012.03.003

Bråthen, S., \& Halpern, N. (2012). Air transport service provision and management strategies to improve the economic benefits for remote regions. Research in Transportation Business \& Management, 4, 3-12.

https://doi.org/10.1016/j.rtbm.2012.06.003

Carnis, L., \& Yuliawati, E. (2013). Nusantara: Between sky and earth could the PPP be the solution for Indonesian airport infrastructures? Case Studies on Transport Policy, 1(1), 18-26. https://doi.org/10.1016/j.cstp.2013.08.003

Cheung, S. O., Lam, T. I., Leung, M. Y., \& Wan, Y. W. (2001). An analytical hierarchy process based procurement selection method. Construction Management \& Economics, 19(4), 427437. https://doi.org/10.1080/014461901300132401

Couper, A. (2015). The geography of sea transport (Vol. 5). London: Routledge. https://doi.org/10.4324/9781315665238

Crowe, T. J., Noble, J. S., \& Machimada, J. S. (1998). Multi-attribute analysis of ISO 9000 registration using AHP. International Journal of Quality \& Reliability Management, 15(2), 205-222. https://doi.org/10.1108/02656719810368495

Doganis, R. (2005). The airport business. London: Routledge. https://doi.org/10.4324/9780203977316

Fasone, V., Maggiore, P., \& Scuderi, R. (2014). Airport ownership and financial performance: evidence from Italy. Journal of Air Transport Management, 40, 163-168. https://doi.org/10.1016/j.jairtraman.2014.07.004

Givoni, M., \& Banister, D. (2007). Role of the railways in the future of air transport. Transportation Planning and Technology, 30(1), 95-112. http://doi.org/10.1080/03081060701208100

Gong, S. X., Cullinane, K., \& Firth, M. (2012). The impact of airport and seaport privatization on efficiency and performance: a review of the international evidence and implications for developing countries. Transport Policy, 24, 37-47. https://doi.org/10.1016/j.tranpol.2012.06.020
Hong Kong Airport Annual Report. (2011). Risk Management Report. Retrieved from https://www.hongkongairport.com/ iwov-resources/file/airport-authority/publications/annualand-interim-reports/en/11_12/E_10_Risk_Management_Report.pdf

Hooper, P. (2002). Privatization of airports in Asia. Journal of Air Transport Management, 8(5), 289-300. https://doi.org/10.1016/S0969-6997(02)00009-1

Ismail, S. (2013). Critical success factors of public private partnership (PPP) implementation in Malaysia. Asia-Pacific Journal of Business Administration, 5(1), 6-19.

https://doi.org/10.1108/17574321311304503

Karim, S. B. A., Rahman, H. A., Berawi, M. A., \& Jaapar, A. (2007). A review on the issues and strategies of stakeholder management in the construction industry. In Meeting and Conference on Management in Construction and Researchers Association (MICRA). Shah Alam, Selangor, Malaysia, University of Malaya.

Leslie, T. F., Frankenfeld, C. L., \& Makara, M. A. (2012). The spatial food environment of the DC metropolitan area: clustering, co-location, and categorical differentiation. Applied Geography, 35(1-2), 300-307. https://doi.org/10.1016/j.apgeog.2012.07.008

Miles, M. B., \& Huberman, A. M. (1994). An expanded resource: qualitative data analysis (2nd ed.). Thousand Oaks, CA: Sage.

Medvedev, A., Alomar, I., \& Augustyn, S. (2017). Innovation in airport design. Aviation, 21(1), 23-28.

https://doi.org/10.3846/16487788.2017.1303542

Morrissey, K. (2014). Producing regional production multipliers for Irish marine sector policy: a location quotient approach. Ocean \& Coastal Management, 91, 58-64. https://doi.org/10.1016/j.ocecoaman.2014.02.006

Nielsen, K. R., \& Elum, C. (2007). Some practical thoughts-risk allocation regarding airport projects in China. In IPBA Conference: Risk Allocations on Airports Session. Beijing, China.

Osei-Kyei, R., \& Chan, A. P. (2015). Review of studies on the critical success factors for Public-Private Partnership (PPP) projects from 1990 to 2013. International Journal of Project Management, 33(6), 1335-1346. https://doi.org/10.1016/j.ijproman.2015.02.008

Paixão, A. C., \& Marlow, P. B. (2002). Strengths and weaknesses of short sea shipping. Marine Policy, 26(3), 167-178. https://doi.org/10.1016/S0308-597X(01)00047-1

Park, J. W., Kim, K. W., Seo, H. J., \& Shin, H. W. (2011). The privatization of Korea's Incheon international airport. Journal of Air Transport Management, 17(4), 233-236. https://doi.org/10.1016/j.jairtraman.2010.09.002

Price, M. (2014). Airport Construction Project Risk Management. Retrieved from https://www.aci-na.org/sites/default/files/ mindy_price_-_construction_risk.pdf

Saaty, T. L. (1980). The analytic hierarchy process. New York: McGraw-Hill.

Saaty, T. L. (2008). Decision making with the analytic hierarchy process. International Journal of Services Sciences, 1(1), 83-98. https://doi.org/10.1504/IJSSCI.2008.017590

Statistics Indonesia (2018). Statistical yearbook of Indonesia. BPSStatistics Indonesia. Retrieved from https://www.bps.go.id/pu blication/2018/07/03/5a963clea9b0fed6497d0845/statistikindonesia-2018.html

Thelle, M. H., \& la Cour Sonne, M. (2018). Airport competition in Europe. Journal of Air Transport Management, 37, 232-248. https://doi.org/10.1016/j.jairtraman.2017.03.005

Thompson, I. B. (2002). Air transport liberalization and the development of third level airports in France. Journal of Transport Geography, 10(4), 273-285.

https://doi.org/10.1016/S0966-6923(02)00043-1 
Ucler, C. (2017). Brainstorming the cryoplane layout by using the iterative AHP-QFD-AHP approach. Aviation, 21(2), 5563. https://doi.org/10.3846/16487788.2017.1344138

Vaidya, O. S., \& Kumar, S. (2006). Analytic hierarchy process: an overview of applications. European Journal of Operational Research, 169(1), 1-29. https://doi.org/10.1016/j.ejor.2004.04.028

Wells, A. T. (1992). Airport planning \& management. New York: TAB Books.

Western Sydney Airport. (2014). Risk matrix. Retrieved from https://westernsydneyairport.gov.au/files/Appendix_D_risk_ matrix.pdf

Woodhead, R. M., \& Berawi, M. A. (2008). An alternative theory of idea generation. International Journal of Management Practice, 3(1), 1-19. https://doi.org/10.1504/IJMP.2008.016044

Wong, J. K., \& Li, H. (2008). Application of the analytic hierarchy process (AHP) in multi-criteria analysis of the selection of intelligent building systems. Building and Environment, 43(1), 108-125. https://doi.org/10.1016/j.buildenv.2006.11.019
World Bank. (2017). Air transport, passengers carried. Retrieved from https://data.worldbank.org/indicator/IS.AIR.PSGR

Yang, X., Tok, S. K., \& Su, F. (2008). The privatization and commercialization of China's airports. Journal of Air Transport Management, 14(5), 243-251. https://doi.org/10.1016/j.jairtraman.2008.04.012

Yoo, K. E., \& Choi, Y. C. (2006). Analytic hierarchy process approach for identifying relative importance of factors to improve passenger security checks at airports. Journal of Air Transport Management, 12(3), 135-142. https://doi.org/10.1016/j.jairtraman.2005.11.006

Zietsman, D., \& Vanderschuren, M. (2014). Analytic hierarchy process assessment for potential multi-airport systems-the case of cape town. Journal of Air Transport Management, 36, 41-49. https://doi.org/10.1016/j.jairtraman.2013.12.0

\section{APPENDIX}

\section{Determining criteria for airport partnership}

\section{Instructions:}

Put a check mark on the criteria scale column (A) or the criteria scale column (B) according to your opinion.

\section{Code definition:}

1: Both criteria equally important;

3: criteria (A) has a moderate importance compared to criteria (B);

5: criteria (A) has a strong importance compared to criteria (B);

7: criteria (A) has a very strong importance compared to criteria (B);

9: criteria (A) has an absolute importance compared to criteria (B).

*Use the even numbers for intermediate values.

Table A1. Pairwise comparison for main criteria

\begin{tabular}{|l|l|l|l|l|l|l|l|l|l|l|l|l|l|l|l|l|l|l|l|}
\hline \multirow{2}{*}{ Criteria A } & \multicolumn{7}{|c|}{ Scale } & \multicolumn{7}{c|}{ Scale } & \multicolumn{1}{c|}{ Criteria B } \\
\hline & 1 & 2 & 3 & 4 & 5 & 6 & 7 & 8 & 9 & 1 & 2 & 3 & 4 & 5 & 6 & 7 & 8 & 9 & \\
\hline Regional economy & & & & & & & & & & & & & & & & & & & Market demand \\
\hline Regional economy & & & & & & & & & & & & & & & & & & & Risk \\
\hline Regional economy & & & & & & & & & & & & & & & & & & & Government Program \\
\hline Regional economy & & & & & & & & & & & & & & & & & & & Accessibility \\
\hline Market demand & & & & & & & & & & & & & & & & & & & Risk \\
\hline Market demand & & & & & & & & & & & & & & & & & & & Government Program \\
\hline Market demand & & & & & & & & & & & & & & & & & & & Accessibility \\
\hline Risk & & & & & & & & & & & & & & & & & & & Government Program \\
\hline Risk & & & & & & & & & & & & & & & & & & & Accessibility \\
\hline Government Program
\end{tabular}


Table A2. Pairwise comparison for sub-criteria

\begin{tabular}{|c|c|c|c|c|c|c|c|c|c|c|c|c|c|c|c|c|c|c|c|c|}
\hline & \multirow{2}{*}{ Criteria A } & \multicolumn{9}{|c|}{ Scale } & \multicolumn{9}{|c|}{ Scale } & \multirow{2}{*}{ Criteria B } \\
\hline & & 1 & 2 & 3 & 4 & 5 & 6 & 7 & 8 & 9 & 1 & 2 & 3 & 4 & 5 & 6 & 7 & 8 & 9 & \\
\hline \multirow{4}{*}{ 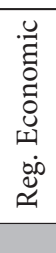 } & GRDP & & & & & & & & & & & & & & & & & & & Ratio GRDP to GDP \\
\hline & GRDP & & & & & & & & & & & & & & & & & & & Featured sector \\
\hline & Ratio GRDP to GDP & & & & & & & & & & & & & & & & & & & Featured sector \\
\hline & & & & & & & & & & & & & & & & & & & & \\
\hline \multirow{7}{*}{ 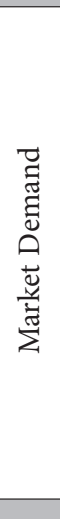 } & $\begin{array}{l}\text { The number of } \\
\text { passengers }\end{array}$ & & & & & & & & & & & & & & & & & & & $\begin{array}{l}\text { The growth in number } \\
\text { of passengers }\end{array}$ \\
\hline & $\begin{array}{l}\text { The number of } \\
\text { passengers }\end{array}$ & & & & & & & & & & & & & & & & & & & The amount of cargo \\
\hline & $\begin{array}{l}\text { The number of } \\
\text { passengers }\end{array}$ & & & & & & & & & & & & & & & & & & & $\begin{array}{l}\text { The growth in the } \\
\text { amount of cargo }\end{array}$ \\
\hline & $\begin{array}{l}\text { The growth in number of } \\
\text { passengers }\end{array}$ & & & & & & & & & & & & & & & & & & & The amount of cargo \\
\hline & $\begin{array}{l}\text { The growth in number of } \\
\text { passengers }\end{array}$ & & & & & & & & & & & & & & & & & & & $\begin{array}{l}\text { The growth in the } \\
\text { amount of cargo }\end{array}$ \\
\hline & The amount of cargo & & & & & & & & & & & & & & & & & & & $\begin{array}{l}\text { The growth in the } \\
\text { amount of cargo }\end{array}$ \\
\hline & & & & & & & & & & & & & & & & & & & & \\
\hline \multirow{6}{*}{$\frac{\underline{y}}{\underline{a}}$} & Politics & & & & & & & & & & & & & & & & & & & Market demand \\
\hline & Politics & & & & & & & & & & & & & & & & & & & Land acquisition \\
\hline & Politics & & & & & & & & & & & & & & & & & & & Tariff \\
\hline & \begin{tabular}{|l|} 
Market demand \\
\end{tabular} & & & & & & & & & & & & & & & & & & & Land acquisition \\
\hline & Market demand & & & & & & & & & & & & & & & & & & & Tariff \\
\hline & Land acquisition & & & & & & & & & & & & & & & & & & & Tariff \\
\hline & & & & & & & & & & & & & & & & & & & & \\
\hline Oت & $\begin{array}{l}\text { Strategic plan of } \\
\text { transportation }\end{array}$ & & & & & & & & & & & & & & & & & & & National Plan \\
\hline \multirow{3}{*}{ 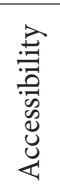 } & Distance & & & & & & & & & & & & & & & & & & & Travel time \\
\hline & Distance & & & & & & & & & & & & & & & & & & & Transport network \\
\hline & Travel time & & & & & & & & & & & & & & & & & & & Transport network \\
\hline
\end{tabular}

